\title{
KARAKTERISTIK SERTA PRINSIP-PRINSIP PENDOKUMENTASIAN ASUHAN KEPERAWATAN
}

\author{
Nuraini Sihite \\ email: nurainisihite4@gmail.com
}

\section{Latar belakang}

Rumah sakit adalah institusi pelayanan kesehatan bagi masyarakat dengan karakteristik tersendiri yang dipengaruhi oleh perkembangan ilmu pengetahuan kesehatan, kemajuan teknologi, dan kehidupan sosial ekonomi masyarakat yang harus tetap mampu meningkatkan pelayanan yang lebih bermutu dan terjangkau oleh masyarakat agar terwujud derajat kesehatan yang setinggi-tingginya.

Dokumentasi merupakan suatu catatan yang memuat seluruh informasi yangdibutuhkan untuk menentukan diagnosa keperawatan, menyusun rencana keperawatan,melaksanakan, mengevaluasi tindakan yang disusun secara sistematis, valid dan dapatdipertanggung jawabkan secara moral dan hukum. Pendokumentasian keperawatantertulis (paper-based documentation) di Indonesia saat ini dilaporkan mutunya masihrendah. Sebagian perawat merasa terbebani dengan waktu yang dihabiskan dalamproses dokumentasi.

Dokumentasi keperawatan merupakan bagian yang penting. Namun pada realitanya dilapangan, dokumentasi keperawatan yang dilakukan masih bersifat manual dankonvensional, belum disertai dengan sistem /perangkat tehnologi yang memadai.

Contohnya:

Dalam hal pendokumentasian asuhan keperawatan masih manual, sehinggaperawat mempunyai potensi yang besar terhadap proses terjadinya kesalahan dalampraktek. Dengan adanya kemajuan teknologi informasi dan komunikasi, maka sangatdimungkinkan bagi perawat untuk memiliki sistem pendokumentasian.

Dokumentasi keperawatan berisi catatan keperawatan sebagai bukti pelaksanaan proses keperawatan dan catatan tanggapan/respon klien/pasien terhadap tindakan medis dan tindakan keperawatan yang telah dilaksanakan. Tanpa dokumentasi keperawatan maka semua implementasi keperawatan yang telah dilaksanakan oleh perawat tidak mempunyai makna dalam hal tanggung jawab dan tanggung gugat. Dokumentasi keperawatan dapat dikatakan 
sebagai "pegangan" bagi perawat dalam mempertanggung jawabkan dan membuktikan pekerjaannya. Oleh karena itu ada berbagai aturan dan kaidah yang harus ditaati oleh setiap perawat dalam melakukan pendokumentasian keperawatan. Dengan proses keperawatan, rasa tanggung jawab dan tanggung gugat bagi perawat itu dapat dimiliki dan dapat digunakan dalam tindakan-tindakan yang merugikan atau menghindari tindakan yang legal. Semua tatanan perawatan kesehatan secara hukum perlu mencatat observasi keperawatan.

Dokumentasi asuhan keperawatan juga sangat diperlukan untuk kepentingan pasien maupun perawat, akan tetapi pada kenyataannya masih banyak dokumen asuhan keperawatan yang isinya belum sesuai baik dari segi kuantitas maupun kualitas.

\section{Metode:}

Metode yang digunakan pada kajian ini adalah metode kualitatif yang memberikan penjelasan dengan menggunakan analisis pada referensi yang digunakan, untuk mengumpulkan data-data dari beberapa jurnal dan e-book dari situs internet yang berhubungan dengan topik pembahasan yaitu karakteristik serta prinsip-prinsip pendokumentasian asuhan keperawatan. Karena keterbatasan waktu, cakupan luas dari topik, dan untuk lebih spesifik, maka dilakukan batasan waktu pada tahun publikasinya dengan waktu minimalnya delapan tahun terakhir yaitu dari tahun 2012 dengan mengambil referensi yang terkait dengan topik yang digunakan.

\section{Hasil}

Proses asuhan keperawatan merupakan tugas dan kewajiban seorang perawat dari pasien datang sampai pasien pulang, dimulai dengan pengkajian secara menyeluruh, kemudian menegakkan diagnosa keperawatan dari data pengkajian tersebut, serta melaksanakan intervensi, implementasi dan evaluasi keefektifan diagnosa awal yang sudah ditegakkan.

Dokumentasi keperawatan berisi catatan keperawatan sebagai bukti pelaksanaan proses keperawatan dan catatan tanggapan/respon klien/pasien terhadap tindakan medis dan tindakan keperawatan yang telah dilaksanakan. Tanpa dokumentasi keperawatan maka semua implementasi keperawatan yang telah dilaksanakan oleh perawat tidak mempunyai makna dalam hal tanggung jawab dan tanggung gugat. Dokumentasi keperawatan dapat dikatakan sebagai "pegangan" bagi perawat dalam mempertanggung jawabkan dan membuktikan pekerjaannya. Oleh karena itu ada berbagai aturan dan kaidah yang harus ditaati oleh setiap perawat dalam melakukan pendokumentasian keperawatan. 


\section{Prinsip-Prinsip Dokumentasi Keperawatan}

Dokumentasi keperawatan mempunyai 3 prinsip yaitu: Brevity, Legibility, dan

Accuracy(Carpenitto, 1991) Prinsip-prinsip tersebut di atas dapat dijelaskan sebagai berikut:

\section{Brevity}

Dalam melakukan pendokumentasian setiap petugas/perawat harus brevity, Brevity sendiri adalah ringkas, jadi kita dalam mencatat isi dokumentasi keperawatan harus ringkas dan tidak perlu memasukan kata; kata atau kalimat yang tidak penting dan mempunyai makna yang tidaksesuai.

\section{Legidibility}

Legidibility yaitu dimana dalam penulisan/pencatatan dokumentasi keperawatan harus mudah dibaca dan di pahami oleh perawat lain atau profesi lain yang ikut dalam proses pendokumentasian.

Misal :

a. Perawat harus menuliskan catatan yang jelas yang bisa dibaca dan di mengerti oleh perawat lain, dan tidak menuliskan istilah-istilah yang tidak di pahami oleh orang lain. Semisal ada istilah baru maka harus segera di diskusikan ke semua tim untuk menggunakan istilah tersebut.

\section{Accuracy}

Accuracy adalah sesuai dengan data yang ada pada klien. Jadi kita harus memasukan data padadokementasi keperawatan harus benar dan sesuai dengan data baik identitas, laboratorium danradiologi pada setiap klien. Ini adalah aspek yang sangat vital dan tidak boleh salah atau tertukardengan klien lain.

Misal :

Dalam memasukan data pemberian obat perawat harus teliti dan tidak boleh salah, obat yangresepkan untuk Tn. A tidak boleh di berikan kepada Tn. C 


\section{Pembahasan}

Proses asuhan keperawatan merupakan tugas dan kewajiban seorang perawat dari pasien datang sampai pasien pulang, dimulai dengan pengkajian secara menyeluruh, kemudian menegakkan diagnosa keperawatan dari data pengkajian tersebut, serta melaksanakan intervensi, implementasi dan evaluasi keefektifan diagnosa awal yang sudah ditegakkan (Nursalam, 2007).

Dokumentasi secara umum merupakan suatu catatan otentik atau semua warkat asli yang dapat dibuktikan atau dijadikan bukti dalam persoalan hukum. Dokumentasi keperawatan merupakan bukti pencatatan dan pelaporan yang dimiliki perawat dalam melakukan catatan keperawatan yang berguna untuk kepentingan klien, perawat dan tim kesehatan dalam memberikan pelayanan kesehatan dengan dasar komunikasi yang akurat dan baiksecara tertulis dengan tanggung jawab perawat (Hidayat, 2007).

Pendokumentasian asuhan keperawatan adalah proses pelaksanaan pencatatan asuhan keperawatan yakni dari pengkajian saat masuk sampai pasien dinyatakan sehat. Diagnosis yang diangkatberdasarkan masalah yang ditemukan, perencanaan keperawatan, tindakan yang dilakukan serta evaluasi dari proses asuhan keperawatan yang diberikan

Dokumentasi keperawatan menurut fisbach (1991) adalah dokumen penting sebagai bukti pelaksanaan tindakan keperawatan yang berisi data lengkap, nyata dan tercatat tentang kualitas dan kuantitas pelayanan kesehatan dalam memenuhi kebutuhan klien yang mencakup bio-psiko-spiritual komprehensif yang diarahkan untuk pengkajian, diagnosis, perencanaan, tindakan dan evaluasi keperawatan dan tersusun secara teratur dan sistematis yang dimasukkan ke dalam format tertentu dan dapat dipertanggungjawabkan secara hukum.

Dokumentasi keperawatan berisi catatan keperawatan sebagai bukti pelaksanaan proses keperawatan dan catatan tanggapan/respon klien/pasien terhadap tindakan medis dan tindakan keperawatan yang telah dilaksanakan. Tanpa dokumentasi keperawatan maka semua implementasi keperawatan yang telah dilaksanakan oleh perawat tidak mempunyai makna dalam hal tanggung jawab dan tanggung gugat. Dokumentasi keperawatan dapat dikatakan sebagai “pegangan" bagi perawat dalam mempertanggung jawabkan dan membuktikan pekerjaannya. Oleh karena itu ada berbagai aturan dan kaidah yang harus ditaati oleh setiap perawat dalam melakukan pendokumentasian keperawatan. 
Dokumentasi proses asuhan keperawatan yang baik dan berkualitas haruslah akurat, lengkap dan sesuai standar. Apabila kegiatan keperawatan tidak didokumentasikan dengan akurat dan lengkap maka sulit untuk membuktikan bahwa tindakan keperawatan telah dilakukan dengan benar.Dokumentasi yang lengkap harus menggunakan standar keperawatan yang digunakan sebagai penilaian kerja perawat dalam melaksanakan asuhan keperawatan mulai dari pengkajian, diagnosa keperawatan, intervensi dan implementasi keperawatan sampai evaluasi.

Tujuan dokumentasi keperawatan adalah menghindari kesalahan, tumpang-tindih dan ketidaklengkapan informasi Keperawatan, terbina nya koordinasi yang baik dan dinamis, meningkatkan efisiensi dan efektivitas tenaga keperawatan, menjaga kualitas keperawatan, melindungi perawat dari keadaan yang memerlukan penanganan hukum serta melindungi klien dari tindakan malpraktek. komponen dokumentasi keperawatan mencakup aspek keterampilan berkomunikasi, mendokumentasikan proses keperawatan dan standar keperawatan. Dalam penerapannya dokumentasi terdiri dari tiga aspek standar yaitu standar tanggung jawab individu perawat profesional standar tanggung jawab profesi dan standar pelayanan kesehatan.

Keberhasilan jaminan mutu rumah sakit salah satu kuncinya adalah dengan pemanfaatan data dan dokumentasi yang bersifat kualitatif dan kuantitatif menjadi informasi yang digunakan sebagai petunjuk dalam pengambilan keputusan yang dilaksanakan secara internal oleh profesi kesehatan dalam organisasi rumah sakit

Ciri dokumentasi asuhan keperawatan yang baik adalah berdasarkan fakta (factual basis), akurat (accuracy), lengkap (completeness), ringkas (conciseness), terorganisir (organization), waktu yang tepat (time liness), dan bersifat mudah dibaca (legability)

\section{Prinsip-Prinsip Dokumentasi Keperawatan}

Dokumentasi keperawatan mempunyai 3 prinsip yaitu: Brevity, Legibility, dan Accuracy(Carpenitto, 1991) Prinsip-prinsip tersebut di atas dapat dijelaskan sebagai berikut:

\section{Brevity}

Dalam melakukan pendokumentasian setiap petugas/perawat harus brevity, Brevity sendiri adalah ringkas, jadi kita dalam mencatat isi dokumentasi keperawatan harus ringkas dan 
tidak perlu memasukan kata; kata atau kalimat yang tidak penting dan mempunyai makna yang tidaksesuai.

4. Legidibility

Legidibility yaitu dimana dalam penulisan/pencatatan dokumentasi keperawatan harus mudah dibaca dan di pahami oleh perawat lain atau profesi lain yang ikut dalam proses pendokumentasian.

Misal :

a. Perawat harus menuliskan catatan yang jelas yang bisa dibaca dan di mengerti oleh perawat lain, dan tidak menuliskan istilah-istilah yang tidak di pahami oleh orang lain. Semisal ada istilah baru maka harus segera di diskusikan ke semua tim untuk menggunakan istilah tersebut.

\section{Accuracy}

Accuracy adalah sesuai dengan data yang ada pada klien. Jadi kita harus memasukan data padadokementasi keperawatan harus benar dan sesuai dengan data baik identitas, laboratorium danradiologi pada setiap klien. Ini adalah aspek yang sangat vital dan tidak boleh salah atau tertukardengan klien lain.

Misal :

Dalam memasukan data pemberian obat perawat harus teliti dan tidak boleh salah, obat yangresepkan untuk Tn. A tidak boleh di berikan kepada Tn. C

Dokumentasi keperawatan adalah setiap catatan baik tertulis maupun elektronik yang menggambarkan layanan keperawatan yang diberikan kepada klien dan dapat digunakan sebagai bukti bagi tenaga yang berwenang. Dokumentasi keperawatan yang berlaku di rumah sakit saat ini umumnya dilakukan secara tertulis (paper based documentation).

Kelebihan dan Kekurangan Dokumentasi keperawatan yang dilakukan pada kertas merupakan catatan yang memerlukan waktu dalam hal menulis. Kegiatan ini mulai dari hal penegakan diagnosis keperawatan, penentuan intervensi dan tindakan keperawatan ini disebabkan karena kurangnya kemampuan perawat dalam hal melakukan analisa. Hal ini juga sulit dianalisis untuk. keperluan penelitian dan mendukung proses pengambilan keputusan klinis. Namun pada dokumentasi berbasis komputerisasi dapat membantu perawat untuk 
mengurangi waktu yang diperlukan dalam proses pendokumentasian sehingga waktu perawat dapat lebih lama kontak dengan pasien dalam memberikan asuhan, dapat mengurangi kesalahan dalam melakukan dokumentasi dan evaluasi hasil tindakan keperawatan yang telah diberikan.

\section{Penutup}

Dokumentasi keperawatan adalah dokumen penting sebagai bukti pelaksanaan tindakan keperawatan yang berisi data lengkap, nyata dan tercatat tentang kualitas dan kuantitas pelayanan kesehatan dalam memenuhi kebutuhan klien yang mencakup bio-psiko-spiritual komprehensif yang diarahkan untuk pengkajian, diagnosis, perencanaan, tindakan dan evaluasi keperawatan dan tersusun secara teratur dan sistematis yang dimasukkan ke dalam format tertentu dan dapat dipertanggungjawabkan secara hukum. Tanpa dokumentasi keperawatan maka semua implementasi keperawatan yang telah dilaksanakan oleh perawat tidak mempunyai makna dalam hal tanggung jawab dan tanggung gugat.

\section{Daftar Pustaka}

Yanti R.I, dkk. 2013. HUBUNGAN KARAKTERISTIK PERAWAT, MOTIVASI, DAN SUPERVISI DENGAN KUALITAS DOKUMENTASI PROSES ASUHAN

KEPERAWATAN. Jurnal Managemen Keperawatan . Volume 1, No. 2

Rosmalia Dewi, Hariyadi. 2019. Dokumentasi keperawatan pada poliklinik gigi (kajian manual dan komputerisasi). Yogyakarta: CV Budi Utama

Siswato L.M.H,dkk. 2013. FAKTOR-FAKTOR YANG BERHUBUNGAN DENGAN KELENGKAPAN PENDOKUMENTASIAN ASUHAN KEPERAWATAN. Jurnal Keperawatan Indonesia, Volume 16 No.2.

Tarigan R, Hanny H. 2019. Manfaat Implementasi Dokumentasi Asuhan Keperawatan Berbasis Komputerisasi Dalam Meningkatkan Mutu Asuhan Keperawatan. Jurnal Ilmiah Kesehatan Pencerah, 08, (2).

Wulandari D.F, Hanny H. 2019. PENGEMBANGAN DOKUMENTASI KEPERAWATAN BERBASIS ELEKTRONIK DI RS X KOTA DEPOK DENGAN MENGGUNAKAN TEORI PERUBAHAN LEWINS. Jurnal Keperawatan Global, Volume 4, No 1. 
Supratti, Ashriady. 2016. PENDOKUMENTASIAN STANDAR ASUHAN

KEPERAWATAN DI RUMAH SAKIT UMUM DAERAH MAMUJU, INDONESIA.

Volume 2, Nomor 1.

Simamora, R. (2009). Dokumentasi Proses Keperawatan.

Simamora, R. H., Purba, J. M., Bukit, E. K., \&Nurbaiti, N. (2019).

PenguatanPeranPerawatDalamPelaksanaanAsuhanKeperawatanMelaluiPelatihanLayanan

Prima. JPPM (JurnalPengabdian Dan PemberdayaanMasyarakat), 3(1), 25-31.

S. Putri W,dkk. 2016. FAKTOR-FAKTOR YANG BERHUBUNGAN DENGAN PENDOKUMENTASIAN ASUHAN KEPERAWATAN DI RUMAH SAKIT JIWA. NERS JURNAL KEPERAWATAN,Volume 12, No 2.

Setiadi. (2012). Konsep dan penulisan dokumentasi proses keperawatan teori dan praktik. Yogyakarta : Graha Ilmu

Pramithasari I. Diah. 2016. Gambaran kinerja perawat dalam mendokumentasikan asuhan keperawatan berbasis komputer di RSUD Banyumas. Jurnal keperawatan Muhammadiyah Vol 1 No 1.

Goni R Nova, dkk. 2018. Hubungan motivasi perawat dengan kepatuhan pendokumentasian asuhan keperawatan di ruangan perawat penyakit dalam RSUD Noongan. E-Jurnal Sariputra, Vol. 5 (1) 